Marketing in Asia Group

\title{
Antecedents of Luxury Brand Consumption: An Emerging Market Context
}

\section{Preeti Tak}

Department of Marketing, Indian Institute of Foreign Trade, India

\begin{abstract}
With dramatic growth of consumption in Indian market, luxury fashion brands have become a domain of growing interest to marketers, academicians and researchers. The study investigates the psychographic factors influencing luxury brand consumption in Indian context. A quantitative and qualitative study was conducted to fulfil the objectives. For qualitative study, in depth interviews were conducted and broad themes were discussed. A structured questionnaire was administered in Delhi. A sample of 423 respondents was analysed. Using structural equation modelling, the study revealed that hedonic, consumer need for uniqueness, price and quality, ostentation, fashion consciousness motivation influence attitude towards luxury brand consumption. However, the findings suggest that social conformity influence attitude towards luxury brands negatively. The findings can be of use to segment the market and positioning of the luxury brands. The findings can also be of help in formulating advertising campaigns of luxury brands. The research will also contribute in academic literature related to luxury brand consumption.
\end{abstract}

Keywords: Luxury Consumers, Hedonic, Need for Uniqueness, Fashion Consciousness, Indian Consumers, Attitude, Intentions.

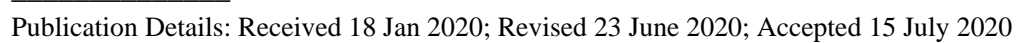




\section{Introduction}

Revenue in the Luxury Goods market in India amounts to US\$10,155m in 2019. The market is expected to grow annually by $2.6 \%$ (CAGR 2019-2023) (Statista, 2019). Louis Vuitton, Gucci and Hermes are the top three brands in India in the luxury segment. The key driver of this growth is the upper middle class who has relied on the education system for high net worth jobs which has subsequently led to higher disposable income. The luxury products market in India continues to experience a high growth rate, with a rising disposable income segment supplementing purchasing decisions that are enabled with the power of technology. Five companies in the top 100 luxury goods are based in India (Deloitte, 2019). An analysis will uncover that individual's aspiration to climb the "consumer ladder" is owing to the fact that they are actually driving India's growth. Luxury brands have been associated to exclusivity, precision, high quality, creative, innovative craftsmanship. These attributes of the product lend the consumers not only the consumption satisfaction, but also added psychological benefits like esteem, status and prestige and reminds and reinforce their exclusivity in their social circle. The concept of luxury has been discussed for centuries. However, what constitutes luxury is still a matter of debate. Luxury has neither been identified and nor defined as to what constitute luxury.

While defining luxury Phau and Prendergast (2000) mentioned that the luxury products are "perceived to be the extreme end of the prestige-brand category". In 1899, Veblen elaborated on the luxury consumption patterns of the "Leisured Class". He maintained that luxury products, when consumed conspicuously can signal wealth and status. Upper class society employs luxury products as an attribute. Chadha and Husband (2006) defined luxury fashion products as "fashionable and high-quality consumer goods made by reputed luxury brands". The definition includes a variety of products such as clothing, footwear and accessories as these goods are widely available and accepted as luxury products (Ahmed, et al., 2002). However, Phau and Prendergast (2000) opined that luxury nowadays represents much more. Sreejesh et al. (2016) related luxury brand aspiration to identity signalling, social recognition, self-esteem and achievement signalling. Vigneron and Johnson (2004) tried to elucidate the complicated nature of defining luxury by mentioning that human involvement, limited supply and recognition of value are the primary components. Thus, luxury should be treated as a subjective matter. The motivations for luxury brand consumption can be classified into two. There are two approaches in terms of perceptions, motivations and behaviour, one "self-referenced" and other one as "other-referenced" (as cited by Amatulii \& Guido, 2011). Self-referenced are the internal motivations and other-referenced are external motivations. The external motivations are related to social and interpersonal motivations. External motivations relate to goals which are essentially aimed at public display of luxury so as to consolidate and confirm the status of the consumer (O'Cass \& Frost, 2002). The second motivations i.e. internal motivations which are subjective and reserved. Internal motivations are concerned with purchase of luxury items based on emotions, state of mind and subjective sensations associated to an individual's self- perception 
(Vigneron \& Johnson, 1999, 2004). Thus, internal motivations were influenced by personal effects and external motivations had interpersonal effects (see table 1).

Table 1: Personal and Interpersonal Effects

\begin{tabular}{|l|l|l|l|}
\hline Effects & Perceptions & Motivations & Behavior \\
\hline Interpersonal & Conspicuous value & Ostentation & Veblenian \\
\cline { 2 - 4 } & Unique Value & Non-conformity & Snob \\
\cline { 2 - 4 } & Social Value & Conformity & Bandwagon \\
\hline Personal & Emotional Value & Self-actualization & Hedonist \\
\cline { 2 - 4 } & Quality Value & Reassurance & Perfectionism \\
\hline
\end{tabular}

Source: Adapted from Vigneron and Johnson (1999)

Recent studies have identified fashion consciousness as a potent factor which influences luxury brand consumption. Fashion has been an important medium to convey the self-concept or of self- image (Kaiser, 1990) and method to create an impression on others (Goldsmith et al., 1991).

Research done in the area of luxury brand has been west focused. Since Indian market has proved itself a promising market for luxury goods, there arises a need to examine whether the previous studies of factors affecting western luxury purchase are still significant and whether they can be applied to Indian consumers. Hence, there is a need to understand the psychological factors that affect the consumption of luxury brands in Indian context. This study explores the phenomenon of luxury brand consumption amongst urban shoppers in Delhi. This research has considered fashion consciousness, the consumer need for uniqueness, social conformity, ostentation, hedonic and quality as motivating factors for luxury brand consumption. The research has also employed Theory of Reasoned Action to fulfil its objectives.

\section{Literature Review and Hypothesis Development}

\section{Fashion Consciousness}

Nam et al. (2006) described fashion consciousness as "a person's degree of involvement with the styles or fashion of clothing". Fashion consciousness is considered a significant factor that influences the adoption of fashion products (Khare and Rakesh, 2010). Consumers who experiment with their clothing and opinion leaders tend to be fashion conscious. They are more inclined to shop at upscale fashion boutiques. They value fashion image and symbolic meaning of clothing. Individuals adopt clothing styles that have symbolic social meaning since it facilitates them to improve their social image. (Shim and Bickle, 1994). Opinion leaders with greater fashion consciousness are more inclined to purchase luxury brands (Jin and Ryu, 2019). Kautish and Sharma (2018) also asserted the significant role of fashion consciousness in influencing consumer's intentions to purchase fashion clothing. It is therefore proposed that: 
H1 Fashion consciousness has positive relationship with attitude towards luxury brands.

\section{Consumer Need for Uniqueness}

Leibenstein (1950) explained consumer need for uniqueness as "snob effect". While describing it, Leibenstein (1950) mentioned that it is state in which the demand for product/item reduces because others are also buying the same product. In 1980, Snyder and Fromkin studied the uniqueness theory and posited that individuals try to achieve moderate level of self- distinctiveness, as they assume that extreme similarity or dissimilarity to the group may lead to unpleasant experience. Tian et al. (2001, p. 52) defined consumer need for uniqueness as:

"....as the trait of pursuing differentness relative to others through the acquisition, utilization, and disposition of consumer goods for the purpose of developing and enhancing one's self-image and social image."

This means that CNFU conveys the increase in self-image and social image. Tian et.al. (2001) categorised the consumers need for uniqueness in three categories of consumer behavior:

1) Creative choice counter-conformity;

2) Unpopular choice counter-conformity; and

3) Avoidance of similarity.

Creative choice counter-conformity refers to consumer behaviour that communicates uniqueness and is also accommodating in accepting others. Kron (1983) proposed that individuals use material goods to communicate their individuality and distinctiveness from the group. They select those material goods that represent their personal style and this desire to communicate personal style is satisfied by possessing unique and novel consumer goods. Unpopular Choice Counter- conformity means usage of such products which is a deviation from the current social and group norms. The individuals at times risk the social disapproval to portray themselves as unique and different from the group. Simonson and Nowlis (2000) mentioned that these individuals are not concerned about criticism from others; in fact, they are inclined to make such purchase decisions which is considered unconventional or unusual by the members of the society. Avoidance of similarity is explained as consuming products which are not very popular and enables the consumers to distinguish themselves from the group. For communicating their distinctiveness, consumers employ various strategies such as buying products from exclusive boutiques. Consumers also get attracted to buy products which discontinued and combine apparels and accessories in unusual manner. Hence, following hypothesis was formulated:

H2 Consumer need for uniqueness has positive relationship with attitude towards luxury brands. 


\section{Ostentation}

This term refers to consumption in which the consumer intends to mark the upper class to which it belongs (or intends to belong) and also establish standards of consumption which correspond to that social hierarchy. Luxury brands are synonym of wealth and status. They indicate the social and economic status of the individual. The main function of these products is to create an impression on others. Chaudhari and Majumdar (2006) suggested ostentation as one of the reasons to purchase luxury brands. Consumers are motivated to purchase luxury brands as it helps in deriving social as well as material satisfaction and enable them in gaining status among his social circles (Chacko et al., 2019). O'Cass and Frost (2002) stressed on the psychological benefits which consumers get from possessions of luxury goods. They gain a sense of belongingness to elite class of the society. Eng and Bogaert (2010) further elaborated the consumers' attitude towards luxury brands and concluded that luxury brands are used for symbolic purpose. Thus, following hypothesis was proposed:

H3 Ostentation has positive impact on attitude towards luxury brands.

\section{Social Conformity}

Social conformity is considered a mirror image to Leibenstein's snob effect (Berry, 1994) driven primarily by a motivation to conform to the societal norms. While discussing Social conformity, Chaudhuri and Majumdar (2006), argued that on one hand consumers purchase luxury brands to enhance their self-concept on the other hand they also attempt to conform to the society's majority opinion. Sanyal et al., (2014) employed Theory of Reasoned Action to study attitude towards luxury goods and posited the importance of reference groups in determining attitude towards luxury brands. Studies have proven that consumers reference griups play an important role in purchase decision making (Cyril Eze er al., 2012). Husic and Cicic (2009) opined that individuals consume luxury goods to communicate some meaning about themselves among their reference groups. Conformity has significant influence on luxury brand consumption (Shaikh et al., 2017). It is therefore proposed that:

H4 Social conformity has positive impact on attitude towards luxury brands.

\section{Hedonic}

Hirschman and Holbrook (1982) pioneered the concept of hedonic consumption and described it as "those facets of consumer behavior that relate to the multisensory, fantasy and emotive aspects of one's experience with products." It is highly likely to arouse emotions as well as these products are associated with sensory impressions such as hopes, dreams, and desires; and emotions of love, envy, and greed. Luxury products can be categorized as "hedonic" as consumers spending pattern is primarily associated with "an affective and sensory experience of aesthetic or sensual pleasure, fantasy and fun" (Dhar \& Wertenbroch, 2000). These types of consumers mainly rely on their personal opinion while purchasing luxury brands. Amaldoss and Jain (2005) 
examined the functions of luxury brands and asserted that luxury brands are utilized by the consumer to satisfy the utilitarian as well as hedonic needs. Vigneron and Johnson (1999) also noted that luxury products have the potential to provide subjective intangible benefits besides delivering the functional benefits. Researchers have also recognized the importance of emotional value provided by luxury brands (Dubois and Laurent, 1994; Vigneron and Johnson, 2004). Hence, following hypothesis was formulated:

H5 Hedonic motivations has positive impact on attitude towards luxury brands.

\section{Price and Quality Motivations}

Luxury brands are associated with status that gives an opportunity to their owners to demand premium prices (Jackson \& Haid, 2002). Luxury is of lately associated with experience; authenticity and emotion while the concept of having the best that money can buy slowly declining (Khor, 2010). Luxury brands have a symbolic value which provides prestige to the bearer of the luxury product. Moore and Birtwistle (2005) opined that scarcity in availability (through enforcement of restrictions on distributions) and they are association with particular customer segments has led to increased appeal and desirability for luxury brands. High prices have a great impact on consumers who view higher value in the products apart from the cost, also associated with a guarantee of quality and reliability from the brand. Functional value of a product is determined by the characteristics of the product which includes reliability, conformance and durability.

Excellent quality is important driving force in luxury market (Quelch, 1987). Consumers evaluate the level of luxury brands by estimating the quality of the product (Vigneron \& Johnson, 1999). Quality value of luxury brands is associated to price/quality schema, which is "...the generalized belief across product categories that the level of the price cue is related positively to the quality level of the product" (Lichtenstein et al., 1993, p. 236). Rao and Monroe (1988) suggested that consumers who are not very aware with luxury products/brands are likely to depend on extrinsic cues such as past experience or price as an indicator of quality. Thus, the individuals who are not very familiar with the brands tend to use high price as a general predictor of quality. Contrary to this, brand conscious consumers have a high susceptibility towards purchasing expensive and popular brands in an impression that higher the price better would be the quality (Sproles \& Kendall, 1986). Kumar (2019) also asserted the importance of quality consciousness among Indian consumers and its relevance in evaluating brand consciousness. Thus, luxury product which are offered at premium prices and coming from a well-known brand tends generate quality value. The consumers may utilize the price/quality or brand name as a parameter for quality. While defining luxury Nueno and Quelch (1998) used price and quality rational and mentioned that whatever falls into high price and quality ration can be categorized as luxury. Following hypothesis was proposed:

H6 Price and Quality has positive impact on attitude towards luxury brands. 


\section{Attitude towards Luxury Brands and Luxury Purchase Intentions}

Fishbein and Ajzen (1975) propounded the Theory of reasoned action and concluded that an individual's attitude and subjective norms influences behavioural intentions. Attitude refers to an individual's favourable or unfavourable evaluation of a specific behaviour whereas beliefs comprises of the information the individual has about the object. Previous studies also suggest that there exists a strong and positive relationship between attitude and intentions in a variety of settings (Loureiro and Araújo, 2014). In the context of this study, attitude can be understood as a user's favourable or unfavourable predisposition towards intentions to purchase luxury brands. Therefore, following hypothesis was formulated:

H7 Attitude towards luxury brands positively influences luxury purchase intentions.

\section{Luxury Purchase Intentions and Luxury Brand Consumption}

Many research studies have discussed intentions influencing consumption. A number of researchers have pointed to the role of intention in predicting behaviour. They consider intentions as the closet cognitive predictor of actual performance behaviour (e.g., Fishbein \& Ajzen, 1975; Fisher \& Fisher, 1992). This suggests that the researcher would be able to predict specific behaviours with significant accuracy from intentions to engage in the behaviours under consideration. In this research the aims would be to predict consumption of luxury brand from intentions. Hence, following hypothesis was proposed:

H8 Luxury purchase intentions influences luxury brand consumption.

\section{Research Method}

\section{Data Collection}

The population under consideration is the urban consumers of Delhi. The sample was selected from Delhi as many industry reports (Sharma, 2018) indicate that Delhi ranked first in spending most on luxury brand in India. A self-administered questionnaire was distributed to the shoppers in the malls of Delhi. A mall intercept survey approach was utilized. Based on rule of thumb, the minimum number of respondents is five-to-one ratio of the number of latent variables to be tested. The participants were briefed about the study. The purpose of the study was mentioned to the participants. This helped the participants in making an informed decision to share their views regarding the survey. They were also assured that only group results will be presented, thus assuring them of their privacy. Total 497 filled in questionnaires were received. However, after thorough data cleaning 423 responses were deemed fit for analysis. The 74 cases were excluded from further analysis due to at least one of the following reasons: 
- $\quad$ some questionnaires suffered from response bias (e.g. all the Likert scale answers were marked strongly agree or strongly disagree)

- Incomplete surveys were also removed.

If the respondent had not marked at least 10 luxury brands from the list of 40 luxury brands listed in the questionnaire, the respondent was not considered as luxury consumer and hence was removed from the sample.

\section{Sample Characteristics}

Table 2 exhibits the demographic features of the sample. 57\% of the respondents were females. Almost two-thirds of the respondents (75\%), aged between 20 and 40 years old. A majority of the respondents (64\%) are post graduates which imply that respondents are well educated. In terms of annual income, $54 \%$ of the respondents had below 9 lakhs of income.

Table 2: Sample Profile

\begin{tabular}{|c|c|c|c|}
\hline Demographics & & $\begin{array}{l}\text { No. of } \\
\text { Respondents }\end{array}$ & $\begin{array}{l}\text { \% of } \\
\text { Respondents }\end{array}$ \\
\hline \multirow[t]{3}{*}{ Gender } & Female & 239 & 57 \\
\hline & Male & 184 & 43 \\
\hline & TOTAL & 423 & 100 \\
\hline \multirow[t]{6}{*}{ Age } & Below 20 & 60 & 14 \\
\hline & $20-30$ & 151 & 36 \\
\hline & $30-40$ & 166 & 39 \\
\hline & $40-50$ & 27 & 6 \\
\hline & Above 50 & 19 & 4 \\
\hline & TOTAL & 423 & 100 \\
\hline \multirow[t]{5}{*}{ Education } & Sr. Secondary & 28 & 7 \\
\hline & Graduation & 107 & 25 \\
\hline & Post-Graduation & 271 & 64 \\
\hline & Others & 17 & 4 \\
\hline & TOTAL & 423 & 100 \\
\hline \multirow[t]{4}{*}{ Annual Family Income } & Below 6 Lakhs & 120 & 28 \\
\hline & 6 Lakhs - 9 Lakhs & 108 & 26 \\
\hline & 9 Lakhs - 12 Lakhs & 72 & 17 \\
\hline & 12 Lakhs - 15 Lakhs & 80 & 19 \\
\hline
\end{tabular}




\begin{tabular}{|l|l|l|l|}
\hline & 15 Lakhs and Above & 43 & 10 \\
\hline & TOTAL & $\mathbf{4 2 3}$ & $\mathbf{1 0 0}$ \\
\hline
\end{tabular}

\section{Questionnaire and Scale Development}

Before designing the research instrument, a qualitative study through in-depth interviews was conducted. The number of respondents interviewed were 15. In-depth interview was conducted to understand the motivations, perceptions towards luxury brands. Awareness level, names of luxury brands etc. were also inquired. After the interview, a list of 40 brands was generated which helped in screening the respondents in the primary survey. The research instrument was designed through a process of drawing from literature, in relation to the constructs being tested. The primary data was collected by using a questionnaire that was distributed to the respondents in Delhi. Furthermore, the questionnaire was pilot tested amongst a small group of sample respondents in Delhi, to test the precision of the instrument. The questionnaire had questions in three sections. The first section deals with the demographic profile of the respondent. The second section covers the consumption and consumption pattern of the consumer. In this section, a list of 40 brands (which was generated from responses given by the respondents in the qualitative research done by the researcher) was given and the respondent was asked to tick as many brands they have consumed. This list acted as screening questions as only those responses were considered for data analysis who has consumed at least 10 brands. Frequency of purchase of luxury brands and categories which they have consumed in past one year was also asked. The last section deals with attitude towards luxury brands and luxury purchase, factors affecting attitude formation towards luxury brands i.e. hedonic, price and quality, fashion-consciousness, ostentation, social conformity and consumer need for uniqueness.

Table 3: Sources of Instruments

\begin{tabular}{|l|c|l|}
\hline Variables & $\begin{array}{l}\text { No. of } \\
\text { Items }\end{array}$ & Items Adapted From \\
\hline Fashion Consciousness & 4 & Bruner, G. and Hensel, P. (1998) \\
\hline Social Conformity & 4 & $\begin{array}{l}\text { Bearden, W., Netemeyer, R., \& Teel, } \\
\text { J. (1989) and Kahle \& Shoham (1995) }\end{array}$ \\
\hline Hedonic & 4 & $\begin{array}{l}\text { Hennigs, N., Wiedmann, K. P., and } \\
\text { Klarmann, C. (2013) }\end{array}$ \\
\hline Ostentation & 4 & Park et al., (2008) \\
\hline Price and Quality & 5 & $\begin{array}{l}\text { Hennigs, N., Wiedmann, K. P., and } \\
\text { Klarmann, C. (2013), Tsai (2005) }\end{array}$ \\
\hline Consumer need for uniqueness & 11 & Tian, Bearden, \& Hunter's (2001) \\
\hline Attitude Towards Luxury brands & 5 & $\begin{array}{l}\text { Dubois, B., Czellar, S., \& Laurent, G. } \\
\text { (2005) }\end{array}$ \\
\hline Luxury Purchase Intention & 5 & Shukla (2010). \\
\hline Luxury Brand Consumption & 6 & Hudders, L., \& Pandelaere, M. (2012) \\
\hline
\end{tabular}


Fashion consciousness was measured by four items derived from Bruner and Hensel's (1998). Conformity was assessed by using four items adapted from Bearden et.al (1989) and Kahle and Shoham (1995), Hedonic was assessed by four statements derived from Hennigs et.al. (2013). Four items measuring ostentation was derived from Park et.al (2008). Price and quality scale comprised of five items which was derived from Hennings et.al (2013) and Tsai (2005). Consumer need for uniqueness scale consisted of eleven items adapted from Tian et.al (2001) which measured three dimensions of need for uniqueness i.e. creative choice counter-conformity, unpopular choice counter-conformity and avoidance of similarity.

Attitude towards luxury brands was measured by a five-item scale derived from behavior related themes of Dubois et.al (2005). Luxury purchase intentions were adopted from Shukla (2012) which measured it with five item scale. These scales were measured on five-point Likert scale where luxury brand consumption was measured by using scale of Hudders and Pandelaere (2012). This must be noted that scale used by Hudders and Pandelaere (2012) measured the self-perceived luxury consumption by taking five material product categories (e.g., clothes and cars) and five experiential product categories (e.g., wine/champagne and travel) that are categorized as major luxury sectors (Danziger 2005). Since this study is focused on fashion apparels only categories related to fashion was only used. There were apparels, footwear, belts, shades, handbags/wallets, wrist watches, accessories. Besides this, a list of 40 luxury brands was used to filter the non-luxury respondents. For data analysis, the study used AMOS 20. Consumer need for uniqueness is operationalized as a reflective second order construct to examine its effect on attitude towards luxury brands. Avoidance of similarity, creative choice counter-conformity and unpopular choice counter-conformity is used as indicators to measure the consumer need for uniqueness. As suggested by Memon et al., (2017) confirmatory factor analysis was performed for all the latent constructs to assess the model fit, convergent validity and discriminant validity.

\section{Results}

\section{Measurement Model}

The results of the measurement model were appropriate by verifying convergent validity, discriminant validity and measurement model fit. First, each measurement had a significant factor loading which ranged .438 to .916 . The critical ratio (t-value) is higher than the critical level of 1.95 with $\mathrm{p}=$ values of .05 . Secondly, for construct reliability, the composite reliabilities were greater than the recommended 0.70 cutoff (Nunnally \& Bernstein, 1994). The values range between 0.817 and 0.929 which suggests that each factor was measured well by all measurements significantly. Lastly, the average variance extracted (AVE) for each construct extracted $50 \%$ or more of the variance. The values range from .501 to .723 which is higher than 0.5 which provides evidence of convergent validity (Hair et al., 2010). The discriminate validity was assessed by comparing the AVE values with the MSV values. As table 4 shows that the MSV values is less than the AVE values, it demonstrates that the constructs do have adequate discriminant validity. 
With respect to the measurement model fit, the Overall chi-square for the measurement model was $\chi 2 / \mathrm{Df}=1.499$. All the fit indices including CFI, IFI, TLI and RMSEA were also greater than .90 or below .05 thresholds, providing strong evidence of good fit of the model to the data (Steiger, 1980). The final results of confirmatory factor analysis (CFA) are reported in Table 5, Table 6 and Table 7.

Table 4: Construct Reliability, Average Variance Extracted and Maximum Shared Variance

\begin{tabular}{|l|l|l|l|}
\hline Constructs & $\begin{array}{l}\text { Composite } \\
\text { Reliability }\end{array}$ & $\begin{array}{l}\text { Average Variance } \\
\text { Extracted }\end{array}$ & $\begin{array}{l}\text { Maximum Shared } \\
\text { Variance }\end{array}$ \\
\hline Fashion Consciousness & 0.895 & 0.680 & 0.035 \\
\hline Consumer Need for Uniqueness & 0.817 & 0.641 & 0.212 \\
\hline Social Conformity & 0.888 & 0.666 & 0.007 \\
\hline Ostentation & 0.828 & 0.559 & 0.035 \\
\hline Hedonic & 0.900 & 0.693 & 0.080 \\
\hline Price and Quality & 0.929 & 0.723 & 0.212 \\
\hline Attitude Towards Luxury Brands & 0.888 & 0.615 & 0.086 \\
\hline Luxury purchase intentions & 0.923 & 0.707 & 0.098 \\
\hline Luxury Brand Consumption & 0.855 & 0.501 & 0.027 \\
\hline
\end{tabular}

Table 5: Correlation Matrix

\begin{tabular}{|c|c|c|c|c|c|c|c|c|c|}
\hline 告 & 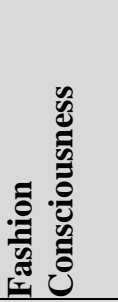 & 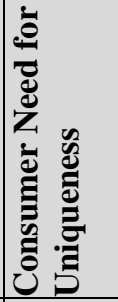 & 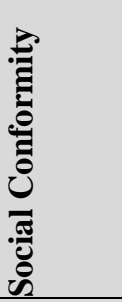 & 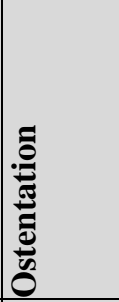 & 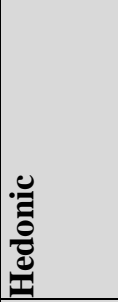 & 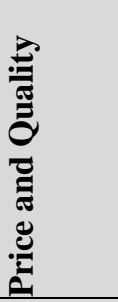 & 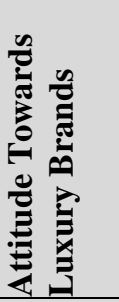 & 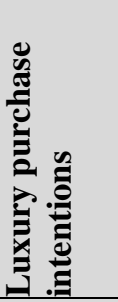 & 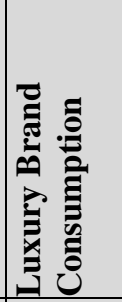 \\
\hline Fashion Consciousness & 0.825 & & & & & & & & \\
\hline $\begin{array}{l}\text { Consumer Need for } \\
\text { Uniqueness }\end{array}$ & 0.359 & 0.801 & & & & & & & \\
\hline Social Conformity & 0.221 & 0.384 & 0.816 & & & & & & \\
\hline Ostentation & 0.188 & 0.284 & 0.305 & 0.748 & & & & & \\
\hline Hedonic & 0.298 & 0.354 & 0.413 & 0.361 & 0.833 & & & & \\
\hline Price and Quality & 0.325 & 0.460 & 0.469 & 0.556 & 0.414 & 0.850 & & & \\
\hline $\begin{array}{l}\text { Attitude Towards Luxury } \\
\text { Brands }\end{array}$ & 0.277 & 0.276 & -0.007 & 0.247 & 0.282 & 0.261 & 0.784 & & \\
\hline Luxury purchase intentions & 0.217 & 0.211 & -0.049 & 0.241 & 0.268 & 0.313 & 0.293 & 0.841 & \\
\hline Luxury Brand Consumption & 0.291 & 0.261 & 0.066 & 0.274 & 0.245 & 0.332 & 0.249 & 0.363 & 0.708 \\
\hline
\end{tabular}


Table 6: Loading for Measurement Model

\begin{tabular}{|c|c|c|c|c|}
\hline Constructs & Items & $\begin{array}{c}\text { Std. } \\
\text { Loading }\end{array}$ & $\begin{array}{l}\text { Std. } \\
\text { Error }\end{array}$ & T-value \\
\hline \multirow{4}{*}{ Fashion Consciousness } & FC 1 & .760 & .046 & 18.882 \\
\hline & FC2 & .843 & .054 & 19.192 \\
\hline & FC3 & .829 & N/A & N/A \\
\hline & FC4 & .863 & .054 & 19.532 \\
\hline \multirow{11}{*}{$\begin{array}{l}\text { Consumer Need for } \\
\text { Uniqueness }\end{array}$} & CNU1 & .559 & .054 & 11.434 \\
\hline & CNU2 & .614 & .054 & 12.768 \\
\hline & CNU3 & .618 & .053 & 12.871 \\
\hline & CNU4 & .861 & N/A & N/A \\
\hline & CNU5 & .638 & .057 & 13.317 \\
\hline & CNU6 & .750 & .058 & 16.122 \\
\hline & CNU7 & .804 & .058 & 17.501 \\
\hline & CNU8 & .799 & N/A & N/A \\
\hline & CNU9 & .916 & .039 & 25.704 \\
\hline & CNU10 & .866 & N/A & N/A \\
\hline & CNU11 & .905 & .044 & 25.315 \\
\hline \multirow{4}{*}{ Social Conformity } & SC1 & .820 & .072 & 16.663 \\
\hline & $\mathrm{SC} 2$ & .842 & .064 & 17.089 \\
\hline & $\mathrm{SC} 3$ & .851 & .060 & 17.256 \\
\hline & SC4 & .748 & N/A & N/A \\
\hline \multirow{4}{*}{ Ostentation } & $\mathrm{O} 1$ & .859 & .064 & 18.400 \\
\hline & $\mathrm{O} 2$ & .799 & .055 & 17.391 \\
\hline & $\mathrm{O} 3$ & .818 & N/A & N/A \\
\hline & $\mathrm{O} 4$ & .438 & .064 & 8.748 \\
\hline \multirow{4}{*}{ Hedonic } & H1 & .818 & .060 & 19.116 \\
\hline & $\mathrm{H} 2$ & .823 & N/A & N/A \\
\hline & $\mathrm{H} 3$ & .823 & .050 & 19.591 \\
\hline & $\mathrm{H} 4$ & .856 & .050 & 20.275 \\
\hline \multirow{5}{*}{ Price and Quality } & PQ1 & .867 & .051 & 20.409 \\
\hline & PQ2 & .811 & .042 & 19.032 \\
\hline & PQ3 & .877 & .049 & 21.641 \\
\hline & PQ4 & .870 & .047 & 21.136 \\
\hline & PQ5 & .824 & N/A & N/A \\
\hline \multirow{5}{*}{$\begin{array}{l}\text { Attitude towards } \\
\text { Luxury Brands }\end{array}$} & ATT1 & .723 & .059 & 15.322 \\
\hline & ATT2 & .834 & .057 & 18.163 \\
\hline & ATT3 & .711 & .066 & 14.516 \\
\hline & ATT4 & .852 & .063 & 18.459 \\
\hline & ATT5 & .791 & N/A & N/A \\
\hline
\end{tabular}




\begin{tabular}{|c|c|c|c|c|}
\hline \multirow{5}{*}{$\begin{array}{l}\text { Luxury Purchase } \\
\text { Intentions }\end{array}$} & INT1 & .823 & .049 & 20.979 \\
\hline & INT2 & .836 & .047 & 21.501 \\
\hline & INT3 & .845 & .046 & 21.883 \\
\hline & INT4 & .854 & N/A & N/A \\
\hline & INT5 & .846 & .046 & 21.929 \\
\hline \multirow{6}{*}{$\begin{array}{l}\text { Luxury Brand } \\
\text { Consumption }\end{array}$} & Apparels & .794 & .062 & 16.255 \\
\hline & Accessories & .491 & .061 & 9.595 \\
\hline & Watches & .692 & .063 & 14.017 \\
\hline & Footwear & .695 & .061 & 14.110 \\
\hline & Shades & .750 & .063 & 15.326 \\
\hline & Handbags & .781 & N/A & N/A \\
\hline
\end{tabular}

Table 7: Model Fit Indices for the Measurement Model

\begin{tabular}{|c|c|c|c|c|c|}
\hline Model & $\chi^{\mathbf{2} / \mathbf{D f}}$ & RMSEA & CFI & TLI & IFI \\
\hline & 1.499 & .034 & .959 & .955 & .959 \\
\hline
\end{tabular}

\section{Structural Model}

To conduct structural equation modelling (SEM) technique, total sample of 423 responses were used for analysis purpose. There were six exogenous (independent) factors and three endogenous (dependent) factors. The results suggest high fit indices indicate the hypothesized model fit the observed data. For the structural model, the value of $\chi 2 / \mathrm{df}=1.483$ which is significant with $\mathrm{p}$-values of .001 . Table 8 presents the summarized result of fit indices.

Table 8: Summary of Model Fit Indices for the Structural Model

\begin{tabular}{|c|c|c|c|c|c|}
\hline Model & $\chi \mathbf{2} / \mathbf{D f}$ & RMSEA & CFI & TLI & IFI \\
\hline & 1.483 & .034 & .960 & .956 & .960 \\
\hline
\end{tabular}

The summarized results of hypothesis testing with structural path estimates are presented in Table 9. Figure 1 exhibits the path coefficients for hypothesis testing.

Table 9: Path Estimates

\begin{tabular}{|l|c|c|}
\hline Hypotheses & Estimates & $\begin{array}{l}\text { Supported/Not } \\
\text { Supported }\end{array}$ \\
\hline H1: Fashion Consciousness ---> Attitude towards Luxury Brands & $.136^{*}$ & Supported \\
\hline H2: Consumer need for uniqueness --->Attitude towards Luxury Brands & $.233^{* *}$ & Supported \\
\hline H3: Ostentation ---> Attitude towards Luxury Brands & $.143^{* *}$ & Supported \\
\hline H4: Social Conformity ---> Attitude towards Luxury Brands & -.024 & Not Supported \\
\hline H5: Hedonic ---> Attitude towards Luxury Brands & $.292^{* *}$ & Supported \\
\hline H6: Price and Quality ---> Attitude towards Luxury Brands & $.179^{* *}$ & Supported \\
\hline
\end{tabular}




\begin{tabular}{|l|l|c|}
\hline H7: Attitude towards Luxury Brands ---> Luxury Purchase Intentions & $.307^{* *}$ & Supported \\
\hline H8: Luxury Purchase Intentions ---> Luxury Brand Consumption & $.169^{* *}$ & Supported \\
\hline
\end{tabular}

Figure 1: Path Coefficients for Hypothesis Testing

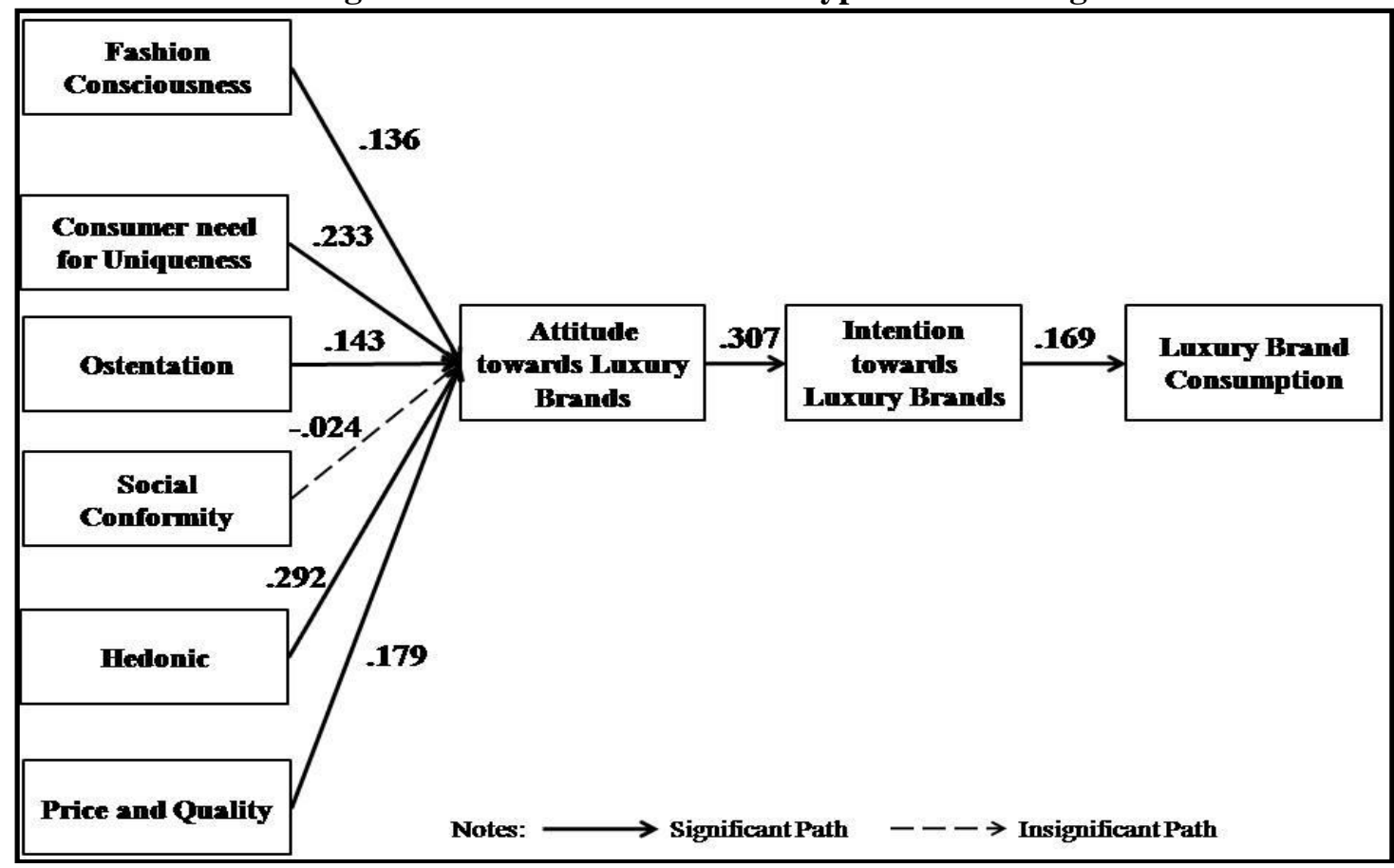

\section{Discussion}

Findings suggest that hedonic motivations have a positive effect on attitude towards luxury brands (H5). Among all the six factors, attitude towards luxury brands is influenced by hedonic motivations the most. This suggests that consumers value the affective and sensory experience of sensual pleasure that they derive from luxury brands. The study also confirms the results of previous studies by Zhong and Mitchell (2010); Amaldoss and Jain (2005) and Dhar and Wertenbroch, 2000) which discussed the hedonic use of luxury brands and mentioned that stressed that luxury brands not only helps in satisfying utilitarian needs but also provides gratification of hedonic needs of the consumers. The results indicate that consumers who are more involved with fashion clothing are more inclined to consumers ${ }^{\text {ee }}$ attitude towards luxury brands. This suggests those consumers who are more fashion consciousness tend to choose luxury brands. The findings are appropriate as previous studies have suggested that luxury brands have been the trend setters. Be it the Haute couture or ready to fashion style, luxury brands have always been at the forefront in being fashion innovators. Tak and Pareek (2016) in their study discussed the role of fashion consciousness in determining the attitude towards luxury brands. Consumers are inclined to communicate their self-image and social image. These two images are interlinked. Consumers tend to nourish these by means of consumption of brands which carry symbolic meaning in the society. Thus, indulging themselves in luxury brand 
consumption. Wu et.al (2015) opined that the social status conferred by expensive luxury fashion brands motivates the consumer to spend more on luxury brands even if their discretionary income was limited.

Findings related to ostentation suggest that the consumer's desire to move up in the social ladder. Consumers want to establish standards of consumption. Shukla (2010) and Eng and Bogaert (2010) stated that expensive luxury brands are not consumed frequently rather consumers prefer consuming occasionally on social gatherings of importance. It facilitates the exhibition of wealth and social status. However, research findings pointed that social conformity influences attitude towards luxury brands (H4) negatively, but the values are insignificant. The study contradicts the findings of Chaudhuri and Majumdar (2006); Berry (1994); and Husic and Cicic (2009) which stressed on role of social conformity in luxury brand consumption. Husic and Cicic (2009) suggested that individuals consume luxury goods in order to conform to the norms of the group to which they belong. Individuals tend to follow other individuals of the society who acts as a reference group. Thus, confirming the "herd" behaviour. However, the research supports the findings of Imhoff and Erb (2009) which suggested that individuals with a high need for uniqueness have less impact of majority influence.

Tepper (1994) also discussed the inconsistent relationships between individual differences in the need for uniqueness and consumer conformity. This study also proposes that consumer need for uniqueness is high among the respondents, while social conformity is negative. Thus, supporting Tepper's (1994) findings. This implies that if the consumer need for uniqueness has inverse relationship with social conformity and hence marketers should position themselves as a brand, offering unique and rare benefits. Study indicated that price and quality positively impact the attitude towards luxury brands (H6). The study supports the findings of Moore and Birtwistle (2005); Vigneron and Johnson, 1999 and Quelch (1987). The study suggests that excellent quality drives consumer to have positive attitude towards luxury brands. High prices of luxury products besides communicating quality of the product help in communicating their symbolic and prestige value. Rao and Monroe (1988); Steenkamp (2010) and others indicated that that consumers who are not familiar and aware about luxury products/brands are likely to search for extrinsic cues such as past experience or price as an indicator of quality.

Findings indicate that attitude towards luxury brand is strong predictor of luxury purchase intentions (H7). The study used theory of reasoned action to adapt the model to suit the needs of the study. Fishbein and Ajzen (1975) propounded the theory of reasoned action and suggested that behavioural intention is determined by the individual's attitude towards the behaviour. Many studies have also pointed the role of attitude in formation of intentions in a variety of settings. The results suggest that attitude towards luxury brands predicts luxury purchase intentions. This is consistent with findings of Loureiro and Araújo (2014). Research also proposed a positive relationship between luxury purchase intentions and luxury brand consumption (H8). 
Study support finding of Fishbein and Ajzen (1975) which stated that intentions is the closet cognitive antecedent of actual performance behaviour.

\section{Theoretical and Managerial Implications}

This study contributed to the literature in luxury marketing by examining the motivations which impact the consumption of luxury brands. The study expands the list of motivations proposed by Vigneron and Johnson (1999) and adds fashion consciousness to it. This is also one of the latest studies which considers ostentation and social conformity as psychological factors in determining luxury brand consumption. This is also one of the few studies that have used consumption as a variable with context to luxury brands. Most of the previous studies have focused on attitude and intentions. Thus, contributing to the store of knowledge on luxury brand consumption particularly in India.

By investigating the effects of psychographic factors on attitude towards luxury brands, findings from this research provides richer explanations of the determinants of certain psychological factors in consumer decision-making. Since the study suggest that hedonic motivation is the most important factor in affecting attitude towards luxury brands, marketers could implement strategies that target this group through positioning luxury fashion brands in accordance with the psychological makeup of hedonic seeking consumers. In case of fashion apparels, marketers can advertise the experience the consumers have during purchase of a product. Also, the in-store atmospherics can also be highlighted in company communication. Store design and ambience of a retail store contributes to hedonic value that customers derive from the shopping experience. The study also showed that consumers are influenced by consumer need for uniqueness and not influenced by social conformity. This finding has important marketing implication as this suggests that marketers could devise a suitable strategy to communicate the unique aspect of the product. For instance, a novel message in an advertisement could be targeted towards consumers in India since consumers have a higher need for uniqueness. Limited availability and exclusivity by mean of constructed scarcity will be an effective marketing strategy to satisfy Indian consumers' high need for uniqueness and help them in avoiding conformity by using luxury brands.

Consumers utilize luxury brands to showcase their status and prestige, so they opt to purchase a luxury brand to communicate about their wealth by acquiring a luxury brand. The results proposed that price and quality effects attitude towards luxury brands. This gives marketers an opportunity to either persuade consumers of an upscale social image or a reliable and credible. As price is used as an indicator or quality, marketers need not think of lowering the price level of the product since this will make the product less desirable. Luxury marketers could implement strategies to target fashion conscious consumers. Fashion campaigns can be designed to attract the fashion forward consumers. Fashion innovators could also be targeted which would help in accelerating consumption of luxury brands. Since study suggests important 
linkage between attitude towards luxury brands and luxury purchase intentions, luxury marketers could exploit this relationship. This help in making informed marketing strategy which suits the needs of the marketers. Advertisements could be directed to aim at increasing target consumers positive attitude towards purchase intentions. For example, for consumers who perceive luxury brands as a signal of wealth, achievement and prestige are likely to be convinced that the luxury brands and its consumers are successful models of the society. Research also proved positive relationship between luxury purchase intentions and luxury brand consumption. This hints the luxury marketers to formulate communication to strengthen the intention and its link to behaviour. For instance, marketers can point the use of luxury brands, such as experience which is worth sharing with consumers peer group and reference group.

\section{Further Research and Limitations}

Future study can explore the role of self-presentation, attitude, materialism and selfmonitoring in influencing the purchase behaviour. The future study can also be directed towards exploratory cross-cultural study with the proposed research questions. A similar research can be undertaken in other cities of India, particularly, the metros due to presence of luxury brands and high disposable income. Other luxury product category such as luxury cars and bikes could be researched under relevant themes to assess the variation in attitude, intention and consumption.

Generalization of the findings of the research is restricted to consumers with similar cultural background. It is not designed to represent behaviours of other cultures and markets. Also, the researcher has focused only on luxury brands, so the information used here cannot address other categories of products such as fast-moving consumer goods and counterfeits. The research has chosen only fashion brands as a category for study and hence sample of different categories may yield different results

\section{Implications for Asian Business Context}

United States and Europe have witnessed sluggish growth. By 2025, the luxury customer base will expand to 450 million, up from 390 million in 2019, backed by the growing middle-class, especially those emerging from Asia (Bain and Co., 2019). This indicates that the global luxury brands are riding on the newfound appetite of Asian consumers for luxury brands. There is a growing appetite for newer luxury brands as well. Luxury brands make the lifestyle statement of the upper middle-class and those in the top echelon. And this clear shift in consumerism has been possible as young Indians are now embracing global luxury brands. Research suggests that with hedonic value draws customers towards luxury fashion brands. This highlights the importance of hedonic value that consumers seek from luxury product or an experience while purchasing it. This suggests that for consumer not only the product is important, but also the in-store experience is also equally important. This indicates that consumers give importance to sensory gratification that derives from luxury 
brands. Rather than the product, the consumers are more concerned about the hedonic benefit they get from the customers. The brands can focus on the experience they offer to the consumer. The in-store experience may comprise the sales people offer their fashion advice which may be useful to the consumer in addition to the trial facility which offered by the stores. Luxury retailers can convey the message of pleasure and experience by offering well organized assortment of high-quality products and an upscale ambience. High prices also lead to scarcity of these goods which further make them more appealing and desirable, hence, providing the consumer with a perceived status and prestige through ownership.

Research also indicates the need for uniqueness drives consumer towards luxury fashion brands. Indianization and localization of luxury brands are becoming differentiator factor. The brands must maintain their exclusivity and reinforce the 'unique style' statement. Several luxury brands have launched wedding ranges in India with customized products such as handbags, scarves. For example, in 2011 Hermes introduced a limited edition of silk sarees and scarves motifs dedicated to colourful culture and heritage of India. The results also suggest that price and quality and ostentation bears influence on consumers. The research proposes that consumers value the luxury brands due to its high price which they attribute to high quality the brands offer. Consumers feel that high price is due to the excellent quality, craftsmanship and aesthetic design of the product. Consumers utilize luxury brands to display their status and prestige, so they are aroused to purchase a luxury brand when they feel that it is imperative for them to acquire a luxury brand to show their wealth. Further, managers should attempt to relate luxury brands with a status value laden messages which emphasize consumers' desire to gain prestige in acquiring luxury brands rather than display. Also, digital platform such as Facebook, Twitter, Blogs, Websites, Instagram, etc. can be used to know the choices of the consumers and products can be customized for regular customers. These platforms can also be used to communicate the process of making of luxury goods which will help the consumers know about the raw materials and the efforts invested in making the product. This will help in reinforcing the consumers' belief in the product and its craftsmanship. Economic growth has created a new generation of moneyed class which comprises of senior corporate, professional and young working men and women who are liberal spenders. Each of these is an attractive segment for the luxury marketers. Luxury marketers may design specific communication themes highlighting social status, professional accomplishments and prestige through the consumption of luxury brands.

\section{References}

Ahmed, A. U., Johnson, J. P., Ling, C. P., Fang, T. W., \& Hui, A. K., (2002), “Country-oforigin and brand effects on consumers' evaluation of cruise lines", International Marketing Review, vol. 19, no. (2/3), pp. 279-302.

Amaldoss, W., \& Jain, S. (2005), "Conspicuous consumption and sophisticated thinking", Management Science, vol. 51, no. 10, pp. 1449-1466.

Assocham Study, (2016), "Indian luxury market to cross $\$ 18.3$ billion by 2016 ", Retrieved from https://economictimes.indiatimes.com/news/company/corporate-trends/indian-lux ury-market-to-cross-18-3-billion-by-2016assocham/articleshow/50480833.cms 
Bain and Company, (2019), "Bain luxury goods worldwide market study, Spring 2019" Retrieved from https://www.bain.com/about/media-center/press-releases/2019/springglobal-luxury-report/ on February 25, 2020

Bearden, W. O., Netemeyer, R. G., \& Teel, J. E., (1989), "Measurement of consumer susceptibility to interpersonal influence", Journal of Consumer Research, vol. 15, no. 4, pp. 473-481.

Berry, C. J., (1994), The idea of luxury: A conceptual and historical investigation, Cambridge University Press, Cambridge.

Bruner, G. C., \& Hensel, P. J., (1998). Marketing scales handbook: A compilation of multiitem measures, American Marketing Association, Chicago.

Chadha, R., \& Husband, P., (2006), The cult of luxury brand: Inside Asia's love affair with luxury, Nicholas Brealey Publishing, London.

Chacko, P. S., Ramanathan, H. N., \& Prashar, S., (2019), "Desire and likeliness to buy luxury products: mapping perceptions using multi-dimensional scaling", International Journal of Indian Culture and Business Management, vol. 18, no. 2, pp. 123-136.

Chaudhuri, H. R., \& Majumdar, S., (2006), "Of diamonds and desires: Understanding conspicuous consumption from a contemporary marketing perspective", Academy of Marketing Science Review, vol. 11, no. 2/3, pp. 2-18.

Cyril Eze, U., Chin, C., \& Lee, C. H., (2012), "Purchasing designer label apparels: The role of reference groups", Asian Journal of Business Research, vol. 2, no. 2, pp. 52-74.

Dabholkar, P. A., \& Bagozzi, R. P., (2002), "An attitudinal model of technology-based selfservice: Moderating effects of consumer traits and situational factors", Journal of the Academy of Marketing Science, vol. 30, no. 3, pp. 184-201.

Danziger, P. M., (2005), Let them eat cake: Marketing luxury to the masses-as well as the classes, Dearborn Trade Publishing, Chicago.

Deloitte, (2019), "Global powers of luxury goods: Bridging the gap between the old and new", Retrieved from https://www2.deloitte.com/content/dam/Deloitte/ar/Documents /Consumer_and Industrial_Products/Global-Powers-of-Luxury-Goods-abril-2019.pdf

Dhar, R., \& Wertenbroch, K., (2000), "Consumer choice between hedonic and utilitarian goods", Journal of Marketing Research, vol. 37, no.2, pp. 60-71.

Dubois, B., \& Laurent, G., (1994), "Attitudes toward the concept of luxury: An exploratory analysis", Asia-Pacific Advances in Consumer Research, vol 1, no.2, pp. 273- 278.

Eng, T. Y., \& Bogaert, J., (2010), "Psychological and cultural insights into consumption of luxury western brands in India", Journal of Customer Behaviour, vol. 9, no. 1, 55-75.

Fishbein, M., \& Ajzen, I., (1975), Belief, attitude, intention, and behaviour: An introduction to theory and research. Addison-Wesley Pub. Co, Reading.

Goldsmith, R. E., Heitmeyer, J. R., \& Freiden, J. B., (1991), "Social values and fashion leadership", Clothing and Textiles Research Journal, vol. 10, no. 1, pp. 37-45.

Hair, J., Black, W., Babin, B., \& Anderson, R., (2010), Multivariate data analysis, PrenticeHall, New Jersey.

Hennigs, N., Wiedmann, K. P., \& Klarmann, C., (2013). "Consumer value perception of luxury goods: A cross-cultural and cross-industry comparison”, In Luxury Marketing, pp. 77-99.

Hirschman, E. C., \& Holbrook, M. B., (1982), "Hedonic consumption: Emerging concepts, methods and propositions", Journal of Marketing, vol. 46 (Summer), pp. 92-101.

Hudders, L., \& Pandelaere, M., (2012), "The silver lining of materialism: The impact of luxury consumption on subjective well-being", Journal of Happiness Studies, vol. 13, no. 3, pp. 411- 437.

Husic, M., \& Cicic, M., (2009), "Luxury consumption factors", Journal of Fashion Marketing and Management, vol. 13, no. 2, pp. 231-245.

Imhoff, R., \& Erb, H. P., (2009), "What motivates nonconformity? Uniqueness seeking blocks majority influence", Personality and Social Psychology Bulletin, vol. 35, no. 3, pp. 309-320. 
Jackson, T., \& Haid, C., (2002), "Gucci group: The new family of luxury brands, a case study", International Journal of New Product Development and Innovation Management, vol. 4, no. 2, pp. 161-172.

Jin, S. V., \& Ryu, E., (2019), "Instagram fashionistas, luxury visual image strategies and vanity", Journal of Product \& Brand Management, vol. 29, no. 3, pp. 355-368.

Kahle, L. R., \& Shoham, A., (1995), "Role-relaxed consumers: Empirical evidence", Journal of Advertising Research, vol. 35, no. 3, pp. 59-62.

Kaiser, S. B., (1990), The social psychology of apparel, Macmillan, New York.

Kautish, P., \& Sharma, R., (2018), "Consumer values, fashion consciousness and behavioural intentions in the online fashion retail sector", International Journal of Retail and Distribution Management, vol. 46, no., 10, pp. 894-914.

Khare, A., \& Rakesh, S., (2010), "Predictors of fashion clothing involvement among Indian youth", Journal of Targeting, Measurement and Analysis for Marketing, vol. 18, no. 3, pp. 209- 220.

Khor, E. T., (2010), "Factors influencing consumer buying behaviour of luxury branded goods", Doctoral dissertation, Universiti Sains Malaysia.

Kron, J., (1983), Home-psych: The social psychology of home and decoration, Potter, New York.

Kumar, A., (2019), "Antecedents of brand consciousness in youth for denim jeans: Evidences from the largest young consumer base in the world", International Journal of Indian Culture and Business Management, vol. 18, no. 3, pp. 330-348.

Leibenstein, H., (1950), "Bandwagon, snob and veblen effects in the theory of consumers' demand", Quarterly Journal of Economics, vol. 64, no. 5, pp. 183-207.

Lichtenstein, D. R., Ridgway, N. M., \& Netemeyer, R. G., (1993), "Price perceptions and consumer shopping behaviour: A field study", Journal of Marketing Research, vol. 30, no. 2, pp. 234-245.

Loureiro, S. M. C., \& de Araújo, C. M. B., (2014), "Luxury values and experience as drivers for consumers to recommend and pay more", Journal of Retailing and Consumer Services, vol. 21, no. 3, pp. 394-400.

Memon, M. A., Ting, H., Ramayah, T., Chuah, F., \& Hwa, C. J., (2017), "A review of the methodological misconceptions and guidelines related to the application of structural equation modelling: A Malaysian scenario", Journal of Applied Structural Equation Modeling, vol.1, no.1, pp. 1-13.

Moore, C. M., \& Birtwistle, G., (2005), "The nature of parenting advantage in luxury fashion retailing - The case of Gucci group NV", International Journal of Retail and Distribution Management, vol. 33, no. 4, pp. 256-270.

Nam, J., Hamlin, R., Gam, H. J., Kang, J. H., Kim, J., Kumphai, P., \& Richards, L., (2007), "The fashion-conscious behaviours of mature female consumers", International Journal of Consumer Studies, vol. 31, no. 1, pp. 102-108.

Nueno, J. L., \& Quelch, J. A., (1998), "The mass marketing of luxury", Business Horizons, vol. 41, no. 6, pp. 61-68.

Nunnally, J. C., \& Bernstein, I. H., (1994), “The assessment of reliability”, Psychometric Theory, vol. 3, pp. 248-292.

O'Cass, A., \& Frost, H., (2002), "Status brands: Examining the effects of non- product-related brand associations on status and conspicuous consumption", Journal of Product and Brand Management, vol. 1, no. 2, pp.67-88.

Park, H. J., Rabolt, N. J., \& Sook Jeon, K., (2008), "Purchasing global luxury brands among young Korean consumers", Journal of Fashion Marketing and Management: An International Journal, vol. 12, no. 2, pp. 244-259.

Phau, I., \& Prendergast, G., (2000), "Consuming luxury brands: The relevance of the rarity principle", Brand Management, vol. 8, no. 2, pp. 122-138.

Quelch, J. A., (1987), "Marketing the premium product", Business Horizons, vol. 30, no. 3, pp. 38-45. 
Rao, A. R., \& Monroe, K. B., (1988), "The moderating effect of prior knowledge on cue utilization in product evaluations", Journal of Consumer Research, vol. 15, no.2, pp. 253-264.

Sanyal, S. N., Datta S. K., \& Banerjee A. K., (2014), "Attitude of Indian consumers towards luxury brand purchase: An application of attitude scale to luxury items", International Journal of Indian Culture and Business Management, vol. 9, no. 3, pp. 316-339.

Sharma, B., (2018), "India's luxury market is currently in a phase of rapid \& dynamic growth", Retrieved from https://www.sundayguardianlive.com/lifestyle/indias-luxurymarket-currently-phase-rapid dyna mic-growth

Shaikh, S., Malik, A., Akram, M. S., \& Chakrabarti, R., (2017), "Do luxury brands successfully entice consumers? The role of bandwagon effect", International Marketing Review, vol. 34, no. 4, pp. 498-513.

Shim, S., \& Bickle, M. C., (1994), "Benefit segments of the female apparel market: Psychographics, shopping orientations, and demographics", Clothing and Textiles Research Journal, vol. 12, no. 2, pp. 1-12.

Shukla, P., (2010), "Status consumption in cross-national context: Socio-psychological, brand and situational antecedents", International Marketing Review, vol. 27, no. 1, pp.108 129.

Shukla, P., (2012), "The influence of value perceptions on luxury purchase intentions in developed and emerging markets", International Marketing Review, vol. 29, no. 6, pp. 574-596.

Simonson, I., \& Nowlis, S. M., (2000), "The role of explanations and need for uniqueness in consumer decision making: Unconventional choices based on reasons", Journal of Consumer Research, vol. 27, no. 1, pp. 49-68.

Snyder, C. R., \& Fromkin, H. L., (1980), Uniqueness: The human pursuit of difference, Plenum, New York.

Sproles, G. B., \& Kendall, E. L., (1986), "A methodology for profiling consumers' decision making styles", Journal of Consumer Affairs, vol. 20, no. 2, pp. 267-279.

Sreejesh S., Abhigyan, S., \& Subhadip, R., (2016), "Validating a scale to measure consumer's luxury brand aspiration", Journal of Product and Brand Management, vol. 25, no. 5, pp. 465-478.

Statista, (2019), "Luxury goods in India", Retrieved from https://www.statista.com/out look/21000000/119/luxury-goods/india

Steenkamp, J. B. E., Van Heerde, H. J., \& Geyskens, I., (2010), "What makes consumers willing to pay a price premium for national brands over private labels?", Journal of Marketing Research, vol. 47, no. 6, pp. 1011-1024.

Steiger, J. H., (1980), "Tests for comparing elements of a correlation matrix", Psychological Bulletin, vol. 87, no. 2, pp. 245.

Tak, P., \& Pareek, A., (2016), "Consumer attitude towards luxury brands: An empirical study", IUP Journal of Brand Management, vol.13, no. 1, pp. 7-19.

Tepper, K., (1994), "Need for uniqueness: An individual difference factor affecting nonconformity in consumer responses" In Marketing theory and applications: Proceedings of the 1994 AMA Winter Educators' Conference, American Marketing Association, Chicago.

Tian, K. T., Bearden, W. O., \& Hunter, G. L., (2001), "Consumers need for uniqueness: Scale development and validation", Journal of Consumer Research, vol. 28, no. 1, pp. 50-66.

Tsai, S., (2005), "Impact of personal orientation on luxury-brand purchase value", International Journal of Market Research, vol. 47, no. 4, pp. 429-454.

Veblen, T., (1899), The theory of the leisure class, MacMillan, New York.

Vigneron, F., \& Johnson, L. W., (2004), "Measuring perceptions of brand luxury", Journal of Brand Management, vol. 11, no. 6, pp. 484-506.

Vigneron, F., \& Johnson, L. W., (1999), “A review and a conceptual framework of prestigeseeking consumer behaviour", Academy of Marketing Science Review, vol 3, no. 1, pp. $15-26$. 
Wu, M. S. S., Chaney, I., Chen, C. H. S., Nguyen, B., \& Melewar, T. C., (2015), "Luxury fashion brands: Factors influencing young female consumers' luxury fashion purchasing in Taiwan", Qualitative Market Research, vol. 18, no. 3, pp. 298-319.

Zhong, J. Y., \& Mitchell, V. W., (2010), "A mechanism model of the effect of hedonic product consumption on well-being", Journal of Consumer Psychology, vol. 20, no. 2, pp. $152-162$. 